der Nachfolge in der Mitgliedschaft in internationalen Konventionen und Organisationen. Es würde zuweit führen, alle Fragen und Probleme aufzuzählen, denen O'Connell bei seiner Untersuchung der Staatenpraxis Beachtung geschenkt hat.

Als Ergebnis ist festzuhalten, daß sich schwerlich eine einheitliche Aussage über die internationale Praxis in den Fragen der Staatennachfolge machen läßt. Um so weniger läßt sich aus der divergierenden Staatenpraxis ein einheitliches Rechtsprinzip ableiten. Gerade auch in diesem Bereich muß man der Erkenntnis O’Connells beipflichten, daß hier das Völkerrecht nicht mehr ist als ein Gehilfe der Diplomatie, und seine Regeln dazu beitragen sollen, das diplomatische Vorgehen zu erleichtern und etwaige Hindernisse aus dem Weg zu räumen (S. 24). Das Buch besticht durch die gründliche und systematische Analyse der umfangreichen Staatenpraxis. Kleinere sachliche Fehler, die hierbei fast zwangsläufig unterlaufen können, wie beispielsweise die Angabe, die VAR sei 1960 aufgelöst worden (so S. 169 und 197) statt des korrekten Datums (28. September 1961), das aber auch (S. 197) gebracht wird, sollten bei einer Neuauflage beseitigt werden. Durch seine ausführlichen Indices und Verzeichnisse der behandelten Verträge und Rechtsprechung übersichtlich ausgestaltet, kann dieses Buch als wichtiges Nachschlagewerk für die Fragen der Staatensukzession nur empfohlen werden.

Gunter Mulack

Maxwell Owusu

Uses and Abuses of Political Power: A Case Study of Continuity and Change in the Politics of Ghana

University of Chicago Press, 1970 Chicago, Pp. XXii +364

Professor Maxwell Owusu's book is mainly concerned with proving the thesis that politics in Ghana, from pre-colonial times to independence and after, has been essentially a struggle about wealth: "... the set of relations concerning the mobilization of resources, of production and exchange, of distribution and allocation of scarce values, primarily defines, establishes, or influences power relationships and patterns of authoritative domination and subordination" (p. 3). Focusing his attention primarily on Swedru, a commercial town in south-central Ghana, Owusu examines both traditional and modern patterns of authority. In the traditional Akan state, the legitimate basis of authority was, in the final analysis, the ability of the rulers to provide for the material well-being of their subjects. The various wars which were fought in the Gold Coast were mainly about the control of trade and commerce, and over the economic resources arising from contact with Europeans. The introduction of cocoa in 1879 made land valuable and most of the dispute in the country after this time were about land and its resources. The need to protect economic interests led to the formation of the Fante Confederation of 1868-71, the Aborigines' Rights Protection Society (1897) and the West African National Congress (1920). Moreover, the United Gold Coast Convention (UGCC) and the Convention People's Party (CPP) had to rely on the articulation of economic grievances and interests for support.

Owusu's detailed examination of the political struggles in Swedru demonstrates the importance of economic power. Most of the inhabitants of this rapidly developing commercial town seemed to be quite indifferent to the ideology of the party they voted for provided it could assure their material well-being. Thus there was no hesitation in switching over from one party to another which was in a position to provide jobs, hospitals, roads, schools and other material 
advantages. It was no accident that opposition to the CPP was strong in areas such as Akim Abuakwa and Kumasi where the traditional rulers, thanks to their control over land and its resources, could dispense patronage.

Owusu's emphasis on the primacy of economics in Ghanaian politics has a very salutary effect: it disposes once and for all, we hope, of the argument that the strength of political parties in Africa may be explained in terms of the charismatic personality of their leaders. In the case of Ghana, it is often alleged that the strength of the CPP was derived largely from the charisma surrounding Nkrumah. The Weberian concept of charisma has always been suspect and whatever value it may have, it is clearly not sufficient to explain, even partially, politics in Ghana. Nobody would deny Nkrumah a certain personal charm and attraction but it would be a gross misunderstanding of the nature of Ghanaian society to contend that he could stay in power for so long $(1951-1966)$ on the basis of the strength of his personality. The true explanation of the force of the CPP, we submit, is that offered by Owusu: "... the strength of the CPP lay in the ability of both Nkrumah and the party, right from the beginning, to appeal to and mobilize generalized or shared instrumental values derived both from the stillimportant traditional Ghanaian cultures and the culture of Eurocolonialism by providing, as a government party, economic opportunities, jobs, and a sense of power to all classes of people, particularly the disadvantaged, on the almost sole basis of membership in the CPP" (p. 249). The CPP rose and fell mainly on economic grounds. Its overall performance, according to the author, was satisfactory (p. 330) and the difficulties faced by Ghana were largely due to the fall in the world price of cocoa.

Here and there, one may find grounds to object to Owusu's interpretation of Ghanaian politics but it will be difficult to dispute his central thesis that in Ghana, as in many developing countries, the true end of politics continues to be primarily wealth. But the importance of this book lies perhaps not so much in its conclusions as in its methods. As Professor Apter points out in his foreword to this book, there has been a long and rich tradition of writing by Ghanaian scholars but Owusu's work is distinguished by its combination of intimate knowledge and professional control. His use of historical, sociological and anthropological methods makes this book a truly interdisciplinary work. He displays an equally high level of sophistication in his handling of economic, legal and administrative questions.

Professor Owusu's work is further confirmation of the belief that the true explanation of African society would have to be done by Africans. The fact that the author, a Ghanaian, had lived in Swedru for eight years and speaks Twi, Ga and Fanti certainly facilitated his research and enabled him to evaluate more accurately whatever information he obtained. He could appreciate the significiance of ethnic stereotypes and joking relationship to an extent which might not have been possible for a non-African. I must add immediately that I am not suggesting that only Africans can understand and explain African society. This would be to ignore the important contribution of British and French scholars to African studies. What I am suggesting is that those who want to explain Africa must know Africa and the Africans. They must come and live with us, and learn our languages. Only an extreme form of arrogance has enabled Europeans and Americans to lecture about Africans after a short stay in Africa (some indeed have never visited the continent) and to pretend to be Africa specialists. Incidentally, no African, even if he has studied or lived in Europe for years, 
would pretend to be Europe specialist or Europeanist. It is astonishing that scholars with no knowledge of African languages can attempt to explain African culture and mentality. The argument that most people in Africa speak English or French is of course false. The elite in most African countries certainly speak English or French but the overwhelming majority of Africans speak only African languages. It is only an assumption that the mass of African peoples are of no importance or have nothing relevant to say which will justify a systematic neglect of their language. Can one imagine scholars writing about, for example, the Germans, without having first studied German on the pretext that the German elite speaks English or French?

His knowledge of the languages spoken in Swedru and in Ghana generally, gives Owusu's work another important quality: liveliness. Whether he is describing struggles for position in the local branch of the CCP, in the district council or attempts to destool a chief, the account he gives is lively and one has the impression he was an eye witness and had talked to all the persons he mentioned in his book. He treats them, not as inanimate objects of a scientific inquiry but as human beings. Owusu has a genuine interest in the persons whose problems he is trying to understand and explain. What is more, he accepts them for what they are, with all their qualities and faults.

One aspect of Owusu's work which is perhaps not very important but nevertheless worth mentioning is his studious avoidance of a German scholar whose name he must have heard at the LSE, University of Chicago and at Harvard. I am referring to Marx. Owusu's thesis that political relations are extensions of economic relations would seem to be in full agreement with Marxist theory.

Whatever reservations one may have about some aspects of this book, one cannot deny that Professor Owusu has made an outstanding contribution to political science and has set new standards in this area.

\section{Dharma Pratap}

Kwame Opoku

\section{The Advisory Jurisdiction of the International Court}

Clarendon Press: Oxford University Press, London etc. 1972, XVI, 292 S., £ 6

Die Gutachterfunktion eines internationalen Gerichts war nach dem Ersten Weltkrieg ein Novum, aber schließlich war es der Ständige Internationale Gerichtshof in dieser Gestalt selbst auch. Die damalige Novität dieser Aufgabe erklärt deren intensive Diskussion nach 1920, die anfängliche Unsicherheit hinsichtlich des $\mathrm{Ob}$ und Wie dieser Jurisdiktion, die mehrfache Änderung der Verfahrensnormen des Gerichts wie auch des Statuts und schließlich die Tatsache, daß die Grundsatzdiskussionen um diese Fragen nach 1945 im Rahmen des ICJ nicht wieder aufgenommen zu werden brauchten. Ursprünglich war sogar die Grundlage für die advisory jurisdiction des PCIJ zweifelhaft: Zwar sah Art. 14 der Völkerbundsatzung sie vor, das ihr gegenüber selbständige Statut schwieg jedoch dazu, und nur mit der etwas gekünstelten Konstruktion einer Inkorporation von Art. 14 VBS in das Statut mittels dessen Art. 1 konnte die Zuständigkeit überhaupt begründet werden. Heute ist diese Frage durch die Integrierung des Statuts in die UN-Charter sowie den besonderen Abschnitt IV des Statuts gelöst. Jene Konstruktion war aber keineswegs unbestritten. Richter J. B. Moore faßte in einem Memorandum 1922 alle Argumente gegen diese Aufgabe des PCIJ zusammen es handle sich hier nicht um eine "appropriate function of a Court of Justice“ 